\title{
LIVER FUNCTION IN A COHORT OF YOUNG HIV-HBV CO-INFECTED PATIENTS ON LONG-TERM COMBINED ANTIRETROVIRAL THERAPY
}

\author{
ADELINA ROȘCA $^{1,2 \#}$, DIANA IACOB ${ }^{3 \#}$, LUMINIȚA ENE $^{4}$, AURA TEMEREANCA ${ }^{1,2}$, \\ CAMELIA GRANCEA ${ }^{2}$, CAMELIA SULTANA ${ }^{1,2}$, CRISTIAN L. ACHIM ${ }^{5}$, SIMONA RUȚA ${ }^{1,2 *}$ \\ ${ }^{I}$ Virology Department, "Carol Davila” University of Medicine and Pharmacy, 8 Eroii Sanitari Street, 050474, Bucharest, \\ Romania \\ ${ }^{2}$ Viral Emerging Diseases Department, “Ștefan S. Nicolau” Institute of Virology, 285 Mihai Bravu Road, 030304, Bucharest, \\ Romania \\ ${ }^{3}$ Infectious Diseases Department, "Carol Davila” University of Medicine and Pharmacy, 8 Eroii Sanitari Street, 050474, \\ Bucharest, Romania \\ ${ }^{4}$ HIVIAIDS Department, “Dr Victor Babeș” Clinical Hospital of Infectious and Tropical Diseases, 281 Mihai Bravu Road, \\ 030303, Bucharest, Romania \\ ${ }^{5}$ Pathology Department, University of California at San Diego, 9500 Gilman, La Jolla, CA 92093, USA
}

*corresponding author: simona.ruta@umfcd.ro

"Authors with equal contribution

Manuscript received: August 2019

\begin{abstract}
HIV-HBV co-infection was previously studied in patients older than 40 years of age, with added risk factors for liver disease. Data on progression of liver damage in young, co-infected patients, without associated comorbidities is sparse. We assessed the prevalence and stage of HBV co-infection in young individuals with parenterally acquired HIV infection and multiple previous antiretroviral (ART) treatments. Out of 227 patients (median age: 24 years, median duration of HIV infection: 23.9 years, median ART duration: 11.6 years), $61.7 \%$ had any markers of $\mathrm{HBV}$ infection, $53.6 \%$ were chronic $\mathrm{HBsAg}$ carriers, 9.3\% had HBeAg present, $11.4 \%$ had high-levels of HBV DNA and 1.4\% had severe liver fibrosis according to FIB-4 noninvasive score. HBV co-infected patients had longer ART exposure (147.07 vs. 121.3 months, $\mathrm{p}=0.003)$ than those with HIVin the absence of HBV, with no significant differences in the use or duration of HIV-HBV dually-active antiretrovirals (lamivudine, tenofovir). Young HIV-HBV co-infected patients remain free of hepatic disease under ART.
\end{abstract}

\section{Rezumat}

Coinfecția HIV-VHB a fost studiată în special la pacienți cu vârsta de peste 40 de ani cu multiplii factori de risc pentru boala hepatică. Există insuficiente date asupra progresiei bolii hepatice la pacienți imunosupresivi cu vârste tinere- Acest studiu evaluează prevalența și stadiul coinfecției cu VHB la pacienți cu infecție HIV dobândită pe cale parenterală, cu multiple tratamente antiretrovirale (ARV) în antecedente. Din 227 de pacienți (vârsta mediană: 24 de ani, durata mediană a infecției HIV: 23,9 ani, durata mediană a ARV: 11,6 ani), 61,7\% au prezentat markeri ai infecției VHB, 53,6\% fiind purtători cronici de AgHBs, dar numai 9,3\% pozitivi pentru AgHBe, $11,4 \%$ cu viremie VHB semnificativă clinic și 1,3\% cu fibroză hepatică severă, evaluată prin scorul neinvaziv FIB-4. Pacienții coinfectați HIV-VHB au avut durată mai mare de expunere la ARV (147,07 vs. 121,3 luni, $\mathrm{p}=$ 0,003) comparativ cu cei monoinfectați HIV, însă fără diferențe semnificative în ceea ce privește utilizarea sau durata ARV cu dublă acțiune pe HIV și VHB (lamivudina, tenofovir). Pacienții tineri coinfectați HIV-VHB rămân într-o fază inactivă a bolii hepatice sub tratament ARV.

Keywords: liver, HIV-HBV coinfection, antiretroviral therapy, viral hepatitis

\section{Introduction}

Hepatitis B virus (HBV) infection is common in individuals infected with HIV; in 2017 around 2.7 million persons were HIV-HBV co-infected, according to the latest WHO estimates [33]. HIV modifies the natural history of $\mathrm{HBV}$ infection, favouring the development of chronic hepatitis and accelerating its course to cirrhosis or hepatocellular carcinoma. As a result, liver-related mortality is estimated to be much higher in HIV-HBV co-infected patients compared to mono-infected ones [28].

In HBV mono-infected individuals, development of cirrhosis is influenced by age, sex, and race; in Caucasian patients, the 5-year cumulative incidence is estimated to be $17-38 \%$, depending on the infective genotype and the presence of $\mathrm{HBe}$ antigen [21]. Individuals infected during childhood are more likely to remain immunotolerant for 20 - 30 years; nevertheless, around $5 \%$ of them will also develop liver fibrosis, 
as it was shown in a study on Taiwanese patients followed for more than a decade [4]. HIV monoinfection is also associated with liver injury, albeit in a smaller proportion of individuals; the rate of liver fibrosis varies between $1.3-4.3 \%$ [2, 12, 16]. In HIV-HBV co-infected patients, in the absence of treatment, the incidence of liver fibrosis is between $12-15 \%$ and there is an increased risk of progression towards cirrhosis and hepatocellular carcinoma [29, 30]. According to both European and American guidelines, HIV patients co-infected with HBV must be treated with antiretrovirals active on both viruses, irrespective of their immune status $[1,5]$. HIV-HBV co-infection was studied mostly in patients older than 40 years of age, with numerous risk factors for liver disease $[3,11]$. Data on the progression of liver damage in young, co-infected patients, without associated comorbidities is sparse.

Romania has one of the largest cohorts of HIV patients infected horizontally in their early childhood, during the early 1990s, via unsterilized needles or blood products $[8,22]$. The prevalence of HBV co-infection in this cohort was high [25], due to the overlapping transmission pathways of the two viruses, in a setting that was endemic for HBV (reported HBV incidence: 43 cases per 100,000 inhabitants, before the introduction of universal new-born vaccination in 1995) [23]. These patients are now aged 23 - 29 years, have lived all their life with HIV (and some of them with HBV coinfection) and have been extensively treated with multiple antiretroviral regimens. They provide a valuable insight on the impact of HIV infection on the evolution of hepatitis B acquired at young ages.

The aim of the current study is to evaluate the frequency and aspects of HBV co-infection and the impact of long-term treatment on liver disease in young patients with longstanding HIV infection.

\section{Materials and Methods}

Patients. A retrospective, cross-sectional study was conducted in patients with HIV infection acquired horizontally in early childhood, followed in a large tertiary facility ("Victor Babeș" Hospital of Infectious Diseases, Bucharest, Romania). Exclusion criteria included a history of chronic hepatitis $\mathrm{C}$ or $\mathrm{D}$, autoimmune hepatitis or hepatocellular carcinoma, pregnancy and breastfeeding. None of the patients had tuberculosis or other AIDS defining diseases at the time of assessment.

HIV infection was virologically characterized by current and zenith viral loads, determined using a commercial nucleic acid amplification test (COBAS TaqMan HIV-1 Test Version 2.0, Roche Molecular Systems, Branchburg, NJ, US), with a linear range between 34 - 10,000,000 copies HIV RNA/mL; values $\leq 34$ HIV RNA copies/mL were classified as undetectable for the analysis. The immunologic status was assessed using current and nadir CD4 cells number, determined using a flow-cytometry based assay (BD Tritest CD4/CD8/CD3, Becton Dickinson, San Jose, CA, US). Current and previous treatment regimens were recorded, as well as previous use of hepatotoxic drugs and self-reported adherence.

Hepatitis B co-infection. Study participants were tested for markers of past (IgG anti-HBc antibodies with or without anti-HBs antibodies) or present (IgG anti$\mathrm{HBc}$ antibodies and $\mathrm{HBsAg}$ ) HBV infection and for $\mathrm{HBV}$ active replication (HBV DNA, HBeAg). HBV viral load was determined using a real-time PCR commercial test (COBAS TaqMan HBV Test, Roche Molecular Systems, Branchburg, NJ, US), with linear range between 6 - 110,000,000 HBV DNA IU/mL; a value $<6 \mathrm{IU} / \mathrm{mL}$ was classified as undetectable for the analysis.

Liver fibrosis was assessed using a non-invasive test, namely the FIB-4 score, derived from the formula: [age (years) $\times$ AST $(\mathrm{IU} / \mathrm{L})] /\left[\right.$ PLT $\left.\left(10^{9} / \mathrm{L}\right) \times \mathrm{ALT}^{1 / 2}(\mathrm{IU} / \mathrm{L})\right]$. A FIB-4 score $<1.45$ was considered a negative predictor for advanced fibrosis, while a score higher than 3.25 was considered suggestive for significant liver fibrosis [14, 31]. ALT values more than $1.5 \mathrm{x}$ upper normal limit (40 IU/mL) were considered elevated.

Other potential hepatotoxic factors. Alcohol use was recorded based on the patient's own assessment (no alcohol consumption, between 1 - 5 drinks a day, more than 5 drinks a day). Alcohol and substance use were recorded as ever or current; none of the study participants met alcohol or substance abuse criteria. Data on plasma cholesterol, triglycerides and body mass index (BMI - assessed using height and weight of the patients) were extracted from the medical records. None of the patients received cholesterollowering statin drugs, none had diabetes, severely immunosuppressed ones received prophylactic trimethoprim-sulfamethoxazole.

Ethics. Approval by the Ethical Committee of "Ștefan S. Nicolau" Institute was granted in accordance with the 2008 Declaration of Helsinki; informed consent was obtained for each participant before the collection of clinical and laboratory data, all analysis were performed on anonymized samples.

Statistical analysis was performed using SPSS software (v21.0; SPSS Inc., Chicago, IL, USA). Nonparametric Mann-Whitney test was employed for assessing differences between groups. Chi-squared test of independence or Fisher exact, where appropriate, was used for qualitative data. Correlations between continuous variables were assessed using Pearson correlation. For all analysis a $\mathrm{p}$ value below 0.05 was considered statistically significant. 


\section{Results and Discussion}

Clinical and laboratory characteristics of patients The demographic, virologic and immunological characteristics of $227 \mathrm{HIV}$-infected patients (median age 24 years, median duration of HIV infection 23.9 years) are presented in Table I. According to the CDC clinical classification, $50.7 \%$ of all patients had previously AIDS defining diseases, $47.6 \%$ were classified as CDC stage B and only $1.8 \%$ as CDC stage A. Current HIV viremia was detectable in $41.9 \%$ patients, with a median viral load in this detectable HIV RNA group of 4610 copies $/ \mathrm{mL}$. The median of the most recent $\mathrm{CD} 4+\mathrm{T}$ cell count was 478.5 cells/ $\mathrm{mm}^{3}$; only $17.2 \%$ of all patients displayed severe immunosuppression (CD4 T cell count below 200 cells $/ \mathrm{mm}^{3}$, out of which more than a half had less than $100 \mathrm{CD} 4$ cells $/ \mathrm{mm}^{3}$ ) (Table I).

Table I

Demographic, virologic, immunologic data in the study groups

\begin{tabular}{|l|c|c|c|c|}
\hline \multirow{2}{*}{ Patients* } & Total & HIV Monoinfection & HIV-HBV Co-infection & P value** \\
\cline { 2 - 5 } & $\mathrm{N}=227$ & $\mathrm{~N}=87$ & $\mathrm{~N}=140$ & \\
\hline Males, $\mathrm{n}(\%)$ & $111(48.9 \%)$ & $41(47.1 \%)$ & $70(50.3 \%)$ & 0.674 \\
\hline Median age, years [IQR] & $24[23 ; 25]$ & $24[23 ; 25]$ & $24[23 ; 25]$ & 0.547 \\
\hline Median BMI, kg/m² [IQR] & $20.43[18.34 ; 23.17]$ & $20.15[18.29 ; 23.39]$ & $20.9[18.68 ; 23.19]$ & 0.510 \\
\hline Cholesterol > 200 mg/dL, n (\%) & $64(28.8 \%)$ & $21(24.1 \%)$ & $43(30.7 \%)$ & 0.370 \\
\hline Triglycerides > 150 mg/dL, n (\%) & $69(31.7 \%)$ & $33(37.9 \%)$ & $36(25.7 \%)$ & 0.034 \\
\hline Median HIV infection duration, years [IQR] & $23.9[22.85 ; 24.65]$ & $23.98[23.08 ; 24.43]$ & $23.87[22.83 ; 24.76]$ & 0.773 \\
\hline No of patients CDC stage C, $\mathrm{n}(\%)$ & $115(50.7 \%)$ & $48(55.2 \%)$ & $67(47.9 \%)$ & 0.239 \\
\hline $\begin{array}{l}\text { Patients with detectable plasma HIV RNA, } \\
\text { n (\%) }\end{array}$ & $95(41.9 \%)$ & $36(41.4 \%)$ & $59(42.1 \%)$ & 0.910 \\
\hline $\begin{array}{l}\text { Median current HIV plasma viral load, } \\
\text { copies/mL [IQR] }\end{array}$ & $1[0 ; 1168]$ & $1[0 ; 467]$ & $1[0 ; 2294.75]$ & 0.678 \\
\hline $\begin{array}{l}\text { Median zenith HIV plasma viral load, } \\
\text { copies/mL [IQR] }\end{array}$ & 133000 & 133000 & 134237.5 & 0.600 \\
\hline Median current CD4, cells/mm ${ }^{3}[\mathrm{IQR}]$ & $478.5[273 ; 700.5]$ & $489[268 ; 698.25]$ & $475.5[273.75 ; 708]$ & 0.694 \\
\hline Patients with CD4 < 200 cells/mL, $\mathrm{n}(\%)$ & $39(17.2 \%)$ & $13(14.9 \%)$ & $26(18.6 \%)$ & 0.505 \\
\hline Median nadir CD4, cells/mm ${ }^{3}[\mathrm{IQR}]$ & $94[22 ; 211]$ & $86[17.5 ; 194]$ & $104.5[24.75 ; 216.75]$ & 0.620 \\
\hline
\end{tabular}

*Continuous data are presented as medians, [IQR]; **Significance was determined using Mann-Whitney U test for continuous variables and Chi-square tests for categorical variables.

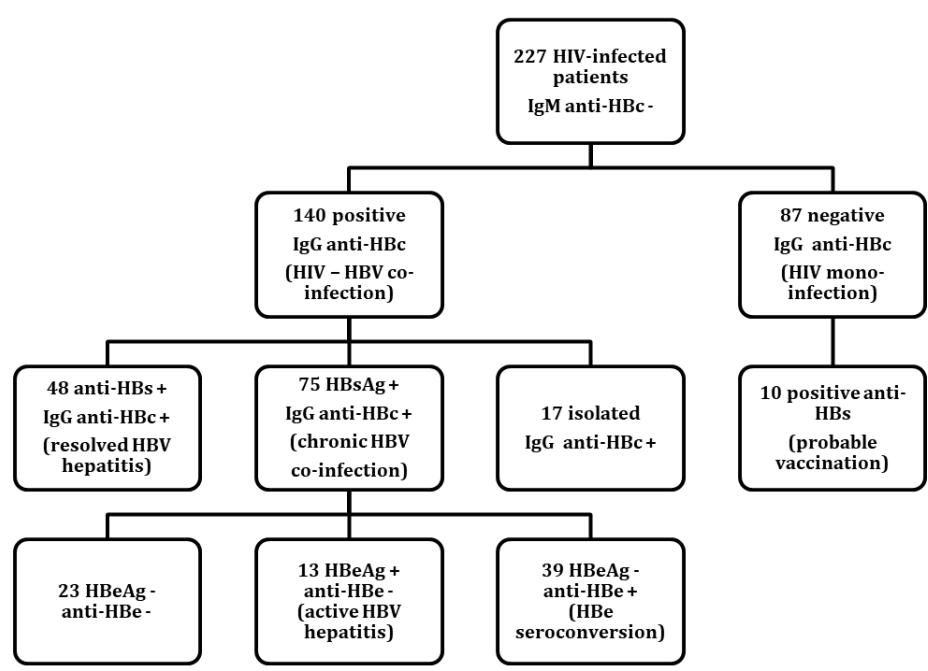

Figure 1.

HIV-HBV co-infection markers in the study group

\section{HBV co-infection}

Co-infection with HBV was detected in 140 (61.7\%) patients (Figure 1), who displayed IgG anti-HBc antibodies as a marker of past or present infection. Half of these patients $(53.6 \%, 75 / 140)$ were chronic HBsAg carriers. Only $9.3 \%$ (13/140) of the co-infected patients presented positive $\mathrm{HBeAg}$, as a marker of active replication. Plasma HBV DNA was detectable in 39 patients, but with a low viral load (median HBV plasma viral load: 12; IQR [12; 357] IU/mL). Clinically relevant viral loads (above $2000 \mathrm{IU} / \mathrm{mL}$ ) were recorded only in 16 cases $(11.4 \%)$ of the co-infected patients, all with positive $\mathrm{HBeAg}$. Plasma HBV DNA viral load was correlated with plasma HIV RNA ( $r=0.407$, $\mathrm{p}=0.0001)$, yet no correlation was recorded with the CD4 T cell count $(\mathrm{p}=0.116)$. Patients without 
severe immunosuppression were less likely to display detectable plasma HBV DNA $(\mathrm{OR}=4.7,95 \% \mathrm{CI}$ : $1.40-16.33$, $\mathrm{p}$ value $=0.010)$.

These data confirms the results obtained in the same setting [25], almost 15 years ago, with a significant prevalence of HBV co-infection in young HIV patients, and higher rates of HBsAg chronic carriage than those recorded in the literature [26].

A third of all co-infected patients $(34.3 \%, 48 / 140)$ have a profile of HBV clearance (IgG anti-HBc and anti-HBs antibodies, without detectable viral load). Longitudinal data were not available to ascertain whether this reflects indeed a high proportion of $\mathrm{HBeAg} / \mathrm{HBsAg}$ loss/seroconversion or whether it is a selection bias. Previous findings reported higher $\mathrm{HBeAg}$ clearance rates in young patients, without comorbidities, compared to older ones, even after prolonged treatment [7].

Seventeen patients displayed isolated anti-HBc antibodies, no cases met the criteria for occult hepatitis (anti-HBc antibodies present, $\mathrm{HBsAg}$ negative, $\mathrm{HBV}$ DNA > $2000 \mathrm{IU} / \mathrm{mL})$. Ten patients $(6.9 \%)$ had isolated anti-HBs antibodies; no data on previous $\mathrm{HBV}$ vaccination status were available.

\section{Liver disease}

Within the entire study group, the median ALT values were within normal limits, namely $37 \mathrm{IU} / \mathrm{mL}$, IQR [29; 49.5]. Co-infected patients were more likely to display ALT values above 1.5 times the upper normal limit $(\mathrm{OR}=2.4,95 \% \mathrm{CI}: 1.08-5.33, \mathrm{p}=0.028)$. The FIB-4 score in the study population was low, with a median value of 0.42 [IQR: $0.32 ; 0.55$ ]. A FIB-4 score above 3.25 (indicative of severe liver fibrosis) was detected only in 3 patients $(1.3 \%$ of the total study population), of which 2 were HBV co-infected. FIB-4 has been shown to have a good negative predictive value for severe fibrosis, and although the use of a non-invasive biomarker could offer imprecise data as to the exact grade of liver

fibrosis, it can be used, along with the FibroMax (Bio Predictive, Paris, France) [19] or the APRI score, in settings where other methods are not readily available [15].

There was no significant correlation between the fibrosis score and other potential causes of hepatotoxicity (high BMI, triglycerides and cholesterol, alcohol use), although the 3 patients with significant liver fibrosis (FIB-4 score over 3.25) reported occasional alcohol consumption.

The low rate of active liver disease, despite the high prevalence of $\mathrm{HBV}$ co-infection, might be attributed to the immunotolerance characteristic for perinatally acquired hepatitis $\mathrm{B}$, but also to the long-term antiretroviral treatment that included HBV active antiretrovirals.

\section{Antiretroviral treatment}

At the time of the study, $90.3 \%(205 / 227)$ of the patients were receiving cART, with no significant differences between the HIV mono-infected and the HIV-HBV co-infected ones regarding the current use of antiretrovirals (Table II). More than half of all individuals had been on ARV medication for over 10 years $(n=128,56.4 \%)$ and received at least 4 different ARV regimens (119/227, 52.4\%, as shown in Table II). The current treatment consisted of NRTI/PI in $75.8 \%$ of all patients, while $9.7 \%$ followed an NRTI/NNRTI-based regimen and $14.5 \%$ received individualized regimens. Participants without cART have stopped their previous treatment and refused to restart ARV, mainly due to pill fatigue.

HIV-HBV co-infected patients had longer treatment durations than HIV mono-infected patients (147.07 vs. 121.3 months, $\mathrm{p}=0.003)$, although no difference was observed between groups in the number of different ARV regimens and no significant differences were recorded regarding all-time use of nucleos(t)ide inhibitors (NRTI), protease inhibitors (PI) or nonnucleoside inhibitors (NNRTI) $(\mathrm{p}>0.5)$.

Table II

Treatment data in the studied groups

\begin{tabular}{|l|c|c|c|c|}
\hline \multicolumn{1}{|c|}{ Treatment data } & Total & HIV Monoinfection & HIV-HBV Co-infection & P value** \\
\hline $\begin{array}{l}\text { Median ARV treatment duration, } \\
\text { months [IQR] }\end{array}$ & $139.54[9464 ; 173.22]$ & $121.3[66.02 ; 164.56]$ & $147.07[104.92 ; 184.31]$ & $\mathbf{0 . 0 0 3}$ \\
\hline Patients currently on ART, n (\%) & $205(90.3 \%)$ & $76(87.4 \%)$ & $129(92.1 \%)$ & 0.343 \\
\hline $\begin{array}{l}\text { Patients with ART regimens for over 10 } \\
\text { years, n (\%) }\end{array}$ & $128(56.4 \%)$ & $40(46 \%)$ & $88(62.9 \%)$ & $\mathbf{0 . 0 3 3}$ \\
\hline $\begin{array}{l}\text { Patients with over 4 different ART } \\
\text { regimens, n (\%) }\end{array}$ & $119(52.4 \%)$ & $41(47.1 \%)$ & $78(55.7 \%)$ & 0.390 \\
\hline $\begin{array}{l}\text { Patients with self-reported adherence } \\
\text { problems, } n(\%)\end{array}$ & $76(33.5 \%)$ & $26(29.9 \%)$ & $50(35.7 \%)$ & 0.578 \\
\hline
\end{tabular}

*Continuous data are presented as medians, [IQR]; **Significance was determined using Mann-Whitney U test for continuous variables and Chi-square tests for categorical variables.

Antiretrovirals active against both HIV and HBV (NRTIs- lamivudine and tenofovir) were equally used in mono-infected and co-infected patients. The current regimen included lamivudine (3TC), used for a median duration of 8 years (in $58.5 \%$ of HIV mono-infected patients and $54.5 \%$ of HIV-HBV coinfected ones, $\mathrm{p}=0.128$ ); and tenofovir (TDF), used for a median duration of 3 years (in $15.8 \%$ of HIV mono-infected and $22 \%$ of HIV-HBV co-infected patients, $p=0.3$ ). With only one exception, all patients 
currently on tenofovir had previously used lamivudine, making it difficult to separate the virologic efficacy of each dually active drug. Nevertheless, TDF- based regimens were used in only 4 of the 16 patients with high HBV viral loads (> $2000 \mathrm{IU} / \mathrm{mL}$ ); all the 4 reported treatment adherence problems and two of them associated high HIV viral loads.

No correlation was observed between the duration of lamivudine or tenofovir treatment and the serological criteria of therapeutic success (seroconversion to antiHBs antibodies or anti-HBe antibodies). However, dually active antiretrovirals have been shown to be effective in reducing both the risk of $\mathrm{HBV}$ reactivation in patients under immune-suppresive and biological modifier therapies [17] and the risk of new HBV infections in HIV infected patients [5, 7]. The importance of long-term treatment with dually active antiretrovirals is also demonstrated by the small number of patients with significant HBV viral loads. HBV viremia has been consistently indicated as the best predictor of liver fibrosis in both HBV mono-infected and HIV-HBV co-infected patients [10, 27, 30]. A gradual regression of fibrosis, following persistent suppression of HBV DNA replication after antiviral treatment has been already signalled [18]. The long treatment duration in patients from our cohort might also account for the low rate of positive $\mathrm{HBeAg}$ hepatitis, as has also been shown in an extensive meta-analysis on HBV mono-infected patients [32]. $\mathrm{HBeAg}$ and/or HBsAg loss are markers of an efficient immune control of HBV replication and together with a sustained virologic response (undetectable viremia) demonstrate the treatment efficacy. Although in this study there was no statistically significant relationship between the use of specific ARV and the presence of liver fibrosis, it is probable that the inclusion of dually active antiretrovirals in the cART regimen for HIV (even without knowing the HBV status), contributed to the low level of viral replication and liver fibrosis. Still, repeated assessments of the liver function are necessary in HIV-HBV co-infected patients, as higher rates of intrahepatic HBV replication can occur irrespective of the HBV plasma viral load [24].

Importantly, the multiple ARV regimens received by the patients over a long period of time did not appear to be associated with significant hepatotoxicity. Similar low rates of liver damage induced by ART have been reported in both HBV and HCV coinfected people living with HIV [13, 20].

\section{Conclusions}

The study demonstrates that young patients with longstanding HIV-HBV co-infection and antiretroviral treatment maintain a low level of HBV replication and have very low rates of active liver disease. Further longitudinal studies are needed to adequately assess the dynamic progression of liver injury from this young age onwards.

\section{Acknowledgement}

This work was partially supported by 1R01MH094159, "Long term effects of chronic HIV infection on the developing brain", from National Institute of Health and by "Carol Davila" University of Medicine and Pharmacy through Contract no. 23PFE/17.10.2018 funded by the Ministry of Research and Innovation within PNCDI III, Program 1 - Development of the National RD system, Subprogram 1.2 - Institutional Performance - RDI excellence funding projects.

\section{Conflict of interest}

The authors declare no conflict of interest.

\section{References}

1. Department of Health and Human Services (HHS) Panel on Antiretroviral Guidelines for Adults and Adolescents (a Working Group of the Office of AIDS Research Advisory Council), Guidelines for the Use of Antiretroviral Agents in HIV-1-Infected Adults and Adolescents, 2012, (https://aidsinfo.nih.gov)

2. Blackard JT, Welge JA, Taylor LE, Mayer KH, Klein RS, Celentano DD, Jamieson DJ, Gardner L, Sherman $\mathrm{KE}, \mathrm{HIV}$ mono-infection is associated with FIB-4 - A noninvasive index of liver fibrosis - In women. Clin Infect Dis., 2011; 52(5): 674-680.

3. Boyd A, Bottero J, Miailhes P, Lascoux-Combe C, Rougier H, Girard PM, Serfaty L, Lacombe K, Liver fibrosis regression and progression during controlled hepatitis B virus infection among HIV-HBV patients treated with tenofovir disoproxil fumarate in France: A prospective cohort study. J Int AIDS Soc., 2017; 20(1): 21426: 1-12.

4. Chu CM, Hung SJ, Lin J, Tai DI, Natural history of hepatitis B e antigen to antibody seroconversion in patients with normal serum aminotransferase levels. Am J Med., 2004; 116(12): 829-834.

5. European Association for the Study of the Liver (EASL), EASL 2017 Clinical Practice Guidelines on the management of hepatitis B virus infection. J Hepatol., 2017; 67(2): 370-398.

6. Gatanaga H, Hayashida T, Tanuma J, Oka S, Prophylactic effect of antiretroviral therapy on hepatitis B virus infection. Clin Infect Dis., 2013; 56(12): 1812-1819.

7. Grant J, Agbaji O, Kramvis A, Yousif M, Auwal M, Penugonda S, Ugoagwu P, Murphy R, Hawkins C, Hepatitis B virus sequencing and liver fibrosis evaluation in HIV/HBV co-infected Nigerians. Trop Med Int Health, 2017; 22(6): 744-754.

8. Hersh BS, Popovici F, Jezek Z, Satten GA, Apetrei RC, Beldescu N, George JR, Shapiro CN, Gayle HD, Heymann DL, Risk factors for HIV infection among abandoned Romanian children. AIDS, 1993; 7(12): 1617-1624.

9. Heuft MM, Houba SM, van den Berk GEL, Smissaert van de Haere T, van Dam AP, Dijksman LM, Regez RM, Brinkman K, Protective effect of hepatitis B 
virus-active antiretroviral therapy against primary hepatitis B virus infection. AIDS, 2014; 28(7): 999-1005.

10. Iloeje UH, Yang H, Su J, Jen C, You S, Chen C, Predicting Cirrhosis Risk Based on the Level of Circulating Hepatitis B Viral Load. Gastroenterology, 2006; 130(3): 678-686.

11. Konopnicki D, Mocroft A, de Wit S, Antunes F, Ledergerber B, Katlama C, Zilmer K, Vella S, Kirk O, Lundgren JD, Hepatitis B and HIV: Prevalence, AIDS progression, response to highly active antiretroviral therapy and increased mortality in the EuroSIDA cohort. AIDS, 2005; 19(6): 593-601.

12. Kooij KW, Wit FWNM, van Zoest RA, Schouten J, Kootstra NA, van Vugt M, Prins M, Reiss P, van der Valk M, AGEhIV Cohort Study Group, Liver fibrosis in HIV-infected individuals on long-term antiretroviral therapy: Associated with immune activation, immunodeficiency and prior use of didanosine. AIDS, 2016; 30(11): 1771-1780.

13. Lapadula G, Costarelli S, Chatenoud L, Castelli F, Astuti N, Di Giambenedetto S, Quiros-Roldan E, Sighinolfi L, Ladisa N, Di Pietro M, Zoncada A, Di Filippo E, Gori A, Nasta P, Torti C, Risk of Liver Enzyme Elevation During Treatment With RitonavirBoosted Protease Inhibitors Among HIV-Monoinfected and HIV/HCV-Coinfected Patients. J Acquir Immune Defic Syndr., 2015; 69(3): 312-318.

14. Li Q, Ren X, Lu C, Li W, Huang Y, Chen L, Evaluation of APRI and FIB-4 for noninvasive assessment of significant fibrosis and cirrhosis in $\mathrm{HBeAg}$-negative CHB patients with ALT $\leq 2$ ULN A retrospective cohort study. Medicine (Baltimore), 2017; 96(12): e6336: 1-7.

15. Li Y, Chen Y, Zhao Y, The diagnostic value of the FIB-4 index for staging hepatitis B-related fibrosis: A meta-analysis. PLoS One, 2014; 9(8): e105728: 1-13.

16. Lim JK, Tate JP, Fultz SL, Goulet JL, Conigliaro J, Bryant KJ, Gordon AJ, Gibert C, Rimland D, Goetz MB, Klein MB, Fiellin DA, Justice AC, Lo Re V, Relationship between alcohol use categories and noninvasive markers of advanced hepatic fibrosis in HIV-infected, chronic hepatitis C virus-infected, and uninfected patients. Clin Infect Dis., 2014; 58(10): 1449-1458.

17. Loomba R, Liang TJ, Hepatitis B Reactivation Associated With Immune Suppressive and Biological Modifier Therapies: Current Concepts, Management Strategies, and Future Directions. Gastroenterology, 2017; 152(6): 1297-1309.

18. Marcellin P, Gane E, Buti M, Afdhal N, Sievert W, Jacobson IM, Washington MK, Germanidis G, Flaherty JF, Schall RA, Bornstein JD, Kitrinos KM, Subramanian GM, McHutchison JG, Heathcote EJ, Regression of cirrhosis during treatment with tenofovir disoproxil fumarate for chronic hepatitis B: A 5-year openlabel follow-up study. Lancet, 2013; 381(9865): 468-475.

19. Morra R, Munteanu M, Imbert-Bismut F, Messous D, Ratziu V, Poynard T, FibroMAXTM: Towards a new universal biomarker of liver disease? Exp Rev Mol Diagn., 2007; 7(5): 481-490.

20. Negru A, Tilișcan C, Tudor AM, Oprea C, Ianache I, Lazăr M, Munteanu D, Mardarescu M, Streinu-
Cercel A, Aramă V, Aramă SS, Identifying the risk factors for low bone mineral density disorders in HIV-positive patients undergoing antiretroviral therapy from the Romanian cohort. Farmacia, 2019; 67(3): 383-391.

21. Park BK, Park YN, Ahn SH, Lee KS, Chon CY, Moon YM, Park C, Han KH, Long-term outcome of chronic hepatitis B based on histological grade and stage. $J$ Gastroenterol Hepatol., 2007; 22(3): 383-388.

22. Patrascu IV, Constantinescu SN, Dublanchet A, HIV-1 infection in Romanian children. Lancet, 1990; 335(8690): 672.

23. Pitigoi D, Rafila A, Pistol A, Arama V, Molagic V, Streinu-Cercel A, Trends in hepatitis B incidence in Romania, 1989-2005. Euro Surveill., 2008; 13(2): pii: 8012.

24. Rivera MM, Soza A, Jazwinski A, Mi L, Kleiner DE, Zhao X, Zuber C, Brust D, Hsu E, Simpson J, Hoofnagle JH, Heller T, HIV through the looking glass: Insights derived from hepatitis B. J Acquir Immune Defic Syndr., 2015; 68(2): 123-127.

25. Ruta SM, Matusa RF, Sultana C, Manolescu L, Kozinetz CA, Kline MW, Cernescu C, High prevalence of hepatitis B virus markers in Romanian adolescents with human immunodeficiency virus infection. J Int AIDS Soc., 2005; 7(1): 68: 1-7.

26. Singh KP, Crane M, Audsley J, Avihingsanon A, Sasadeusz J, Lewin SR, HIV-hepatitis B virus coinfection: Epidemiology, pathogenesis, and treatment. AIDS, 2017; 31(15): 2035-2052.

27. Stockdale AJ, Phillips RO, Beloukas A, Appiah LT, Chadwick D, Bhagani S, Bonnett L, Sarfo FS, Dusheiko G, Geretti AM, Liver Fibrosis by Transient Elastography and Virologic Outcomes after Introduction of Tenofovir in Lamivudine-Experienced Adults with HIV and Hepatitis B Virus Coinfection in Ghana. Clin Infect Dis., 2015; 61(6): 883-891.

28. Sun HY, Sheng WH, Tsai MS, Lee KY, Chang SY, Hung CC, Hepatitis B virus coinfection in human immunodeficiency virus-infected patients: A review. World J Gastroenterol., 2014; 20(40): 14598-14614.

29. Thio CL, Smeaton L, Saulynas M, Hwang H, Saravan S, Kulkarni S, Hakim J, Nyirenda M, Iqbal HS, Lalloo UG, Mehta AS, Hollabaugh K, Campbell TB, Lockman $\mathrm{S}$, Currier JS, Characterization of HIV-HBV coinfection in a multinational HIV-infected cohort. AIDS, 2013; 27(2): 191-201.

30. Wandeler G, Mulenga L, Vinikoor MJ, Kovari H, Battegay M, Calmy A, Cavassini M, Bernasconi E, Schmid P, Bolton-Moore C, Sinkala E, Chi BH, Egger $\mathrm{M}$, Rauch A, Liver fibrosis in treatment-naïve HIVinfected and HIV/HBV co-infected patients: Zambia and Switzerland compared. Int J Infect Dis., 2016; 51: 97-102.

31. WHO, Guidelines for the prevention, care and treatment of persons with chronic hepatitis B infection, 2015.

32. Xing T, Xu H, Cao L, Ye M, HBeAg seroconversion in $\mathrm{HBeAg}$-positive chronic hepatitis B patients receiving long-term nucleos $(\mathrm{t})$ ide analog treatment: A systematic review and network meta-analysis. PLoS One, 2017; 12(1): 1-18.

33. WHO, Global Hepatitis Report, 2017. 